\title{
Yield response of cucumber (Cucumis sativus L.) to different fertigation levels
}

\section{MANGAL PATIL AND S.B. GADGE}

Received : 23.07.2016; Revised : 19.08.2016; Accepted : 05.09.2016

See end of the Paper for authors' affiliation

Correspondence to :

\section{MANGAL PATIL}

Department of Irrigation and

Water Management Engineering, College of

Technology and Engineering,

Maharana Pratap University

of Agriculture and

Technology, UDAIPUR

(RAJASTHAN) INDIA

Email : mangalpati143@

gmail.com
- ABSTRACT : A field experiment was conducted at the Instructional Farm of Department of Irrigation and Drainage Engineering, Mahatma Phule Krishi Vidyapeeth, Rahuri, to study effect of different fertigation levels on cucumber (var. Gypsy) production under shade net house with 35, 50 and 75 per cent shading with open field trial. Amongst growth attributes, days to 50 per cent flowering, average diameter of the fruit, average length of fruit, average weight of fruit, length of vine were recorded and were significantly influenced by fertigation. Application of 125 per cent NPK through drip irrigation recorded maximum yield of $21.87 \mathrm{t} \mathrm{ha}^{-1}$ also showed maximum net income followed by application of 125 per cent $\mathrm{N}$ through drip irrigation and soil application $\mathrm{P}$ and $\mathrm{K}$ as basal dose of a $21.61 \mathrm{tha}^{-1}$. The maximum FUE was observed with 100 per cent NPK through drip irrigation system $(68.73 \mathrm{~kg} / \mathrm{kg})$.

- KEY WORDS : Fertigation, Cucumber, Biometric parameters

- HOW TO CITE THIS PAPER : Patil, Mangal and Gadge, S. B. (2016). Yield response of cucumber (Cucumis sativus L.) to different fertigation levels. Internat. J. Agric. Engg., 9(2) : 145-149, DOI: 10.15740/ HAS/IJAE/9.2/145-149. 